The next point I would like to make has to do with the degree of penetration of international treaty obligations in Islamic law. Most Muslim states that have ratified any of the international conventions on human rights have done so with the reservation that such obligations are not incompatible with the Sharià. The issue would arise, for instance, with respect to article 18 of the International Covenant on Civil and Political Rights on the right of freedom of religion. The limitations permitted under paragraph 3 of the article is that the freedom to manifest one's religion or belief may be subject to restriction in order to protect public order, or public morals. Can a Muslim state thus limit the application of the freedom of religion to the three monotheistic faiths? This has been the issue in a major case in Egypt concerning the exercise of the Baha'i faith, to which I will refer briefly, and which has some application to the Rushdie matter.

The Egyptian Constitution provides that Islam is the higher source of law in Egypt, and yet there is a secular constitution that Egypt is subject to as well. The constitution provides for freedom of religion, much as article 18 of the Covenant does. Egypt ratified the International Covenant, and thus is bound by article 18. However, a Presidential Decree by Mr. Nasser in 1960 prohibited the Baha'i from having temples and exercising their religion in temples. In 1984, a small number of Baha'i decided to gather and participate in a religious ceremony. Some overzealous state police decided to arrest them and bring suit against them. The prosecutor general of the "State Security Laws of Exceptions" refused to prosecute the case, finding that this did not constitute a violation of State Security Laws. The case was then foisted upon the ordinary criminal prosecutor and of the 51 persons accused, 3 were found guilty and received 3-year sentences, which were suspended. They were held on a minor monetary bail. An appeal was filed and the Court of Appeals very courageously found that the facts did not warrant the conviction, setting aside the lower court's conviction. The Court of Appeals of Cairo ruled in a way that was reminiscent of Marbury $v$. Madison. The Court found that it had jurisdiction over the matter, recognized the applicability of the International Covenant subject to the limitation under article 18(3) which Egypt had ratified, and recognized the right of freedom of religion under the Constitution, but concluded that since the Baha'i in their public exercise of religion might create a negative reaction by Muslim fundamentalists, "public order" justified the 1960 Decree that they not exercise their beliefs publicly. The court emphasized that they can do so privately, and thereby maintain their freedom of religion.

This is the sort of middle road that a secular Islamic state can follow and yet remain somewhat consistent with internal human rights law. Such a position stands in sharp contrast to the blatant abuse of both Islamic law and international law that Khomeini used in condemning Rushdie to death in absentia and without trial.

\title{
The New International Holy Alliance and the Struggle to APPROPRIATE AND CENSOR GENERAL CULTURAL SYMBOLS
}

$$
\text { by W. Michael Reisman* }
$$

Give me the souls; take thou the property for thyself. (Genesis 14:21)

The issue we are addressing today has been precipitated by Salman Rushdie's novel Satanic Verses but it is not about the book itself nor even about the atrocious treatment Rushdie has received. Yet there have been so many misrepresentations of the book and its author, that we must begin with some facts about them.

\footnotetext{
*Wesley N. Hohfeld Professor of Jurisprudence, Yale Law School.
} 
Satanic Verses, as anyone who has read it knows, is not, in any way, designed to incite racial or religious hatred or discrimination or urge or condone acts of violence. It is not hate literature. It is a work of serious literary ambition by a modern secularized Muslim who, like all artists, reworks the great symbols and myths of his culture through his own psyche in the context of contemporary events, perspectives, and value conflicts. It is a universal book, in the sense in which literature aspires, for though key parts of its symbol dialects are Islamic and Indian as well as those of the modern industrial West, it explores universal human experiences and may be read and appreciated by readers from entirely different cultural traditions. It is, moreover, a book in which many of the characters are caught up in real spiritual quests, in which the temptations and ecstacies of conscious evil have their day but in which forgiveness, self-knowledge, and real virtue are ultimately understood and triumph. But if the book is spiritual, even religious, it is not "approved"; it was not published with a nihil obstat and an official imprimatur. It is not reverent, in the sense of deferring to and reinforcing the standard authorized or politically "correct" religious interpretation.

Our Chairman has related some of the history of Satanic Verses but has left out some important events. When Salman Rushdie published Satanic Verses, in 1988, notices of the book and exaggerations about it, much more than its physical appearance or actual contents, sparked large-scale and repeated riots in India and induced the Indian Government on October 5, 1988, to prohibit its publication in that country. On February 14, 1989, the Ayatollah Khomeini denounced the book. As Imam, he condemned Rushdie to death. He ordered his assassination, promising the killer both spiritual and monetary rewards, the latter rapidly augmented by others in Iran. The Ulema in Saudi Arabia put the book on trial as heretical. The European Community recalled its ambassadors from Iran and the United Kingdom suspended diplomatic relations, with a strong protest over the targeting of a British national for assassination. After a short time, the Europeans returned.

The Rushdie affair quickly became one more example of how terrorism works. Threats at bookstores in the United States caused a number of distributors to remove the books from shelves, while European publishers suspended plans for bringing out editions there. Counterprotests from different parts of the American community secured the reversal of the bookstores' decisions and a coalition of Western European writers arranged to publish Rushdie themselves. Rushdie himself went into hiding under police protection and, Galileo-like, publicly apologized for any offense he may have caused.

Within a short period of time, other voices in the West made themselves heard in a chorus of most unexpected harmony. The refrain was tolerance, freedom of religion, and consideration. But, curiously, it was not a criticism of the Islamic actions. Religious leaders of the Catholic church, a number of Protestant churches, the Chief Rabbi of Great Britain, one of the Chief Rabbis of Israel, and a born-again former President all joined to deplore the book and its publication. Some Western leaders affirmed their commitment to freedom of expression but, in the name of tolerance (and perhaps trade), also allowed a sympathy and understanding for Islamic indignation. Some criticized the contents of Rushdie's book.

The more dramatic elements of the Rushdie affair are actually the least novel. The real challenge that the incident poses to the emerging global civilization has largely been missed. The Ayatollah Khomeini's assassination ukase against a foreign national was unprecedented only in its openness and theatricality. Western political philosophy, at least from the 10th century, has argued the justifications and conditions of tyrannicide. Contemporary governments have arranged for assassinations of foreign 
nationals. Stalin arranged Leon Trotsky's, by then a scrivener exiled to Mexico, and countless unnamed others. John Kennedy reportedly took out a contract with organized crime figures on the life of Fidel Castro. Enough is known about U.S. involvement in the death of Salvador Allende to be troubling. Mossad has arranged the assassination of PLO leaders. More recently, Ronald Reagan made little secret of one of the legally unintended but ardently hoped-for consequences of the raid on Tripoli.

I am not suggesting for a moment that these prior incidents have established a norm legitimizing state-sponsored assassinations. I am, however, concerned to show that Khomeini was no pioneer in this aspect of the Rushdie affair. If Khomeini innovated anything in this matter, it was the audacious openness of his action, one more manifestation that he, too, like a character in a Genet play, is an artist of imposing theatricality who seeks to dominate the world's stage.

Nor is the prohibition of publication of certain types of materials unprecedented or, for all purposes, necessarily unlawful. Many of the Islamic states that condemned Rushdie's novel (indeed many non-Islamic states) do not have effective regimes of freedom of expression, so the prohibition of the publication of one more book is lamentable but in itself not remarkable. Many states that do have approximations of genuine freedom of expression systems allow for the prohibition of publication of certain . types of material. In Canada, for example, materials that incite racial or religious hatred may be suppressed. Even in the United Kingdom, works that are blasphemous to Christianity may be prohibited; indeed, one such work was recently barred.

Nor are such prohibitions alien to international law and, indeed, to international human rights law. Article 4 of the Convention on the Elimination of All Forms of Racial Discrimination requires states parties to punish "all dissemination of ideas based on racial superiority or hatred" and "incitement to racial discrimination." This obligation is quite separate from an obligation to suppress communications that actually incite racial discrimination and violence.

The severe punishment of religious dissenters is also no recent development in parts of the Muslim world nor is the demand for ideological conformity in those states which are increasingly fundamentalist. Rushdie's novel is not the first to incur widespread wrath. Recall the fate of Nobel Laureate Mahfouz's apparently benign fictitious treatment of the life of the Mohammed or the short and turbulent history of the recent cinematic presentation of the life of the Prophet. In each case, clerical and then popular reaction was intense and threatened violence.

The things the Islamic world has been most criticized for in the Rushdie affair are not unique or uniquely Islamic. Once the issue was officially framed in terms of blasphemy and the Muslim public was aroused, what followed was precedented and predictable. The media reaction, which focused on the most dramatic and telegenic aspects, actually served to divert attention from the gravest issue in the incident.

What is most striking and I submit, disturbing, in the Rushdie incident is not the religious reaction in the East, which was largely predictable, but the religious reaction in the West. I refer to the de facto international holy alliance that has spontaneously formed, and to the support lent by religious leaders in the West to a key part of Khomeini's and other Muslim cleric's claim. In the name of religious tolerance and consideration for the feelings of others, a new type of broad spiritual intolerance is being proposed. If we bear in mind that the book in question does not incite violence or preach hatred, we will see that a common motive of the religious hierarchy in key parts of Christendom, Judaism, and Islam has been the sympathy expressed for the Ayatollah's claim of the right to exclusive control of major symbols of the global culture and the prerogative of deciding how they are to be used artistically. By impli- 
cation, these same leaders are asking the secular state apparatus to enforce their property rights in their symbols.

"Their property"? "Their symbols"? The Koran, the Old and New Testaments, the Vedas are all texts that are venerated as divine revelation by some but are also repositories of many if not most of the key symbols and myths of their respective civilizations. The Koran is also the dominant linguistic and stylistic influence for all Arab speakers. Even for non-Muslims in the Arabic speaking world, the symbols, myths, legends, and basic conceptions of the Koran have infiltrated general cultural consciousness. The symbols and myth systems of the Old and New Testaments have had a corresponding impact on Western civilization. The contents of all of these books constitute a key part of the symbol system, the inner life, if you will, of all the members of these various civilizations, whatever their religion or lack of it.

Is religious or social tolerance the issue here? If it were simply a matter of agreeing not to say things that upset others, like not remarking, in their presence, on Smith's baldness or Jones' obesity (the way decent but not very thoughtful people like Jimmy Carter seem to see the problem), all Rushdie affairs could be resolved quickly and easily. But that is not the issue. The unexpected spontaneous alliance between the Ayatollah and his new-found allies among clerical leaders of Christendom and Judaism over the Rushdie incident represents a common, mutually reinforcing claim by the bureaucracies of each of these various religions for ownership of "their" respective symbols and the right to make the ultimate decisions about how they may be used. Each of these religions is now asking that the secular power of the state be put at their disposal for enforcing their decisions in this regard. Ironically, their claim is made in the name of tolerance and consideration. If they are permitted to accomplish their aim, a powerful and widespread censorship may henceforth be exercised over key parts of the inner lives, not simply of artists, not simply of scientists, but of all members of these cultural and language systems.

Freedom of thought and expression are not luxuries that we can suspend and adapt and balance against other social goals and interests. Freedom of thought and expression are at the very core of the dynamics of our industrial and science-based civilization. The presence of those freedoms here is why New York is one of the centers of a dynamic civilization and Qom is not.

Neither art nor science invents things, for there is nothing new. Art and science push back the boundaries of consciousness so that artists, scientists, and their audiences are made aware of and are able to use things that had formerly been unseen, obscure, or repressed. Satirists do this intentionally by lifting the mask of pretension and piercing the veil of self-delusion. These processes of discovery are, for many people who have invested key parts of their egos in certain symbols, values, or social arrangements, a painful experience, for it forcefully alters, "amputates," as McLuhan described it, the inner images that people make of themselves and the world.

Sometimes the troublesome innovator is suppressed, like Molière, Joyce, Bulgakov. Sometimes the innovator must recant, like Galileo and Rushdie. Sometimes, like Solzhenitsyn, he is exiled. Sometimes the reaction, as in Socrates' case, is more violent. But the violence is the fault of those who oppose this process and we cannot stop it just to protect their feelings. The pain and the struggle engendered are necessary costs if the collective consciousness is to remain a dynamic process, including rectitude and religion.

For the custodians of orthodoxies, religious or secular, those who push at the boundaries and tilt at the totems-artists and scientists alike-are uniquely dangerous and wicked. In one of the eerily prescient exchanges in Rushdie's novel, Baal, an 
artist, who has said, "I recognize no jurisdiction except that of my Muse," is sentenced to death by the Prophet, Mahound. He says to Mahound, "Whores and writers ... We are the people you can't forgive." Mahound replies, "Writers and whores. I see no difference here."

The process of discovery at the heart of our civilization cannot be contained or guided, as Russia and China have belatedly learned. This process stimulates itself, feeds on itself and where it operates, creativity, inventiveness, and productivity abound. If the process is restricted or suppressed, science is choked off into theology and art becomes iconography. Both deteriorate from a process in which the boundaries of consciousness are always pushed back, in an ongoing and cumulating collective enrichment, to a communal Rubik cube, in which a limited number of approved elements are moved feverishly around in an ever-decreasing number of "new" combinations.

The holy alliance that has emerged from the Rushdie affair is more than a threat to freedom of expression. It threatens the very scientific and artistic creativity of our civilization. It is a greater threat than was the now moribund New International Information Order. No one can be permitted to appropriate the general symbols of civilization and then license others to use them under prescribed conditions. Those symbols are transmitted from generation to generation, enriched by each, and are the true common heritage of mankind.

ANETA B. SHAPARIS*

Reporter

\title{
New Prospects and INItiatives for a REVIVED UNITED NATIONS
}

\author{
The panel was convened by its Chair, Thomas Franck, ${ }^{* *}$ at 2:30 p.m., April 7,
} 1989.

\section{REMARKS BY ThOMAS FRANCK}

This meeting convenes at an extraordinarily interesting juncture in the affairs of states. In recent times, matters have changed so rapidly that reform of the Charter and of the United Nations system itself has become not only desirable or necessary, but, more important for diplomacy, realistic.

This panel is meant to discuss the breathtaking transformation of the potential for change in the U.N. system from starry-eyed academic wishful thinking and navel gazing, to a realistic exercise. The discussion will not be in terms of outcomes or specific solutions to world problems, but in terms of a transformation of the system by which problems are addressed multilaterally.

\section{Remarks by Thomas R. Pickering***}

Having been at the United Nations for only 2 weeks, it is easier for me to address the context of the subject than the substance. The United Nations is changing rapidly,

\footnotetext{
"Chicago, Illinois.

* Professor of Law, New York University School of Law.

***United States Permanent Representative to the United Nations. Ambassador Pickering spoke in his personal capacity.
} 